\title{
Dis/place/ment: The Life and In/animacy of Rocks and Stories
}

\author{
Ashley Campbell-Ghazinour \\ Independent Scholar, New York \\ aelizcampbell@gmail.com
}

\begin{abstract}
In this illustrated article, I begin with a question: Do rocks talk? The life, movement and migration of stories - and rocks, as the oldest living beings, have witnessed these histories and transformations (Donald, 2009; Tinker, 2004). This article explores the changing landscapes and stories of our lives, and the places where we live and dwell. It unravels discourses seeped in colonial histories, while recognizing our responsibilities as newcomers and settlers to these places and Indigenous peoples. This métissage of stories speaks to the meaning of places within our lives - and what we can learn from these places, when and if, we are willing to listen. And rocks, as the oldest living beings, always remember.
\end{abstract}

Keywords: In/animacy of rocks and stories, disrupting dominant colonial narratives, Truth and Reconciliation 


\section{Introduction}

\section{Campus Rock}

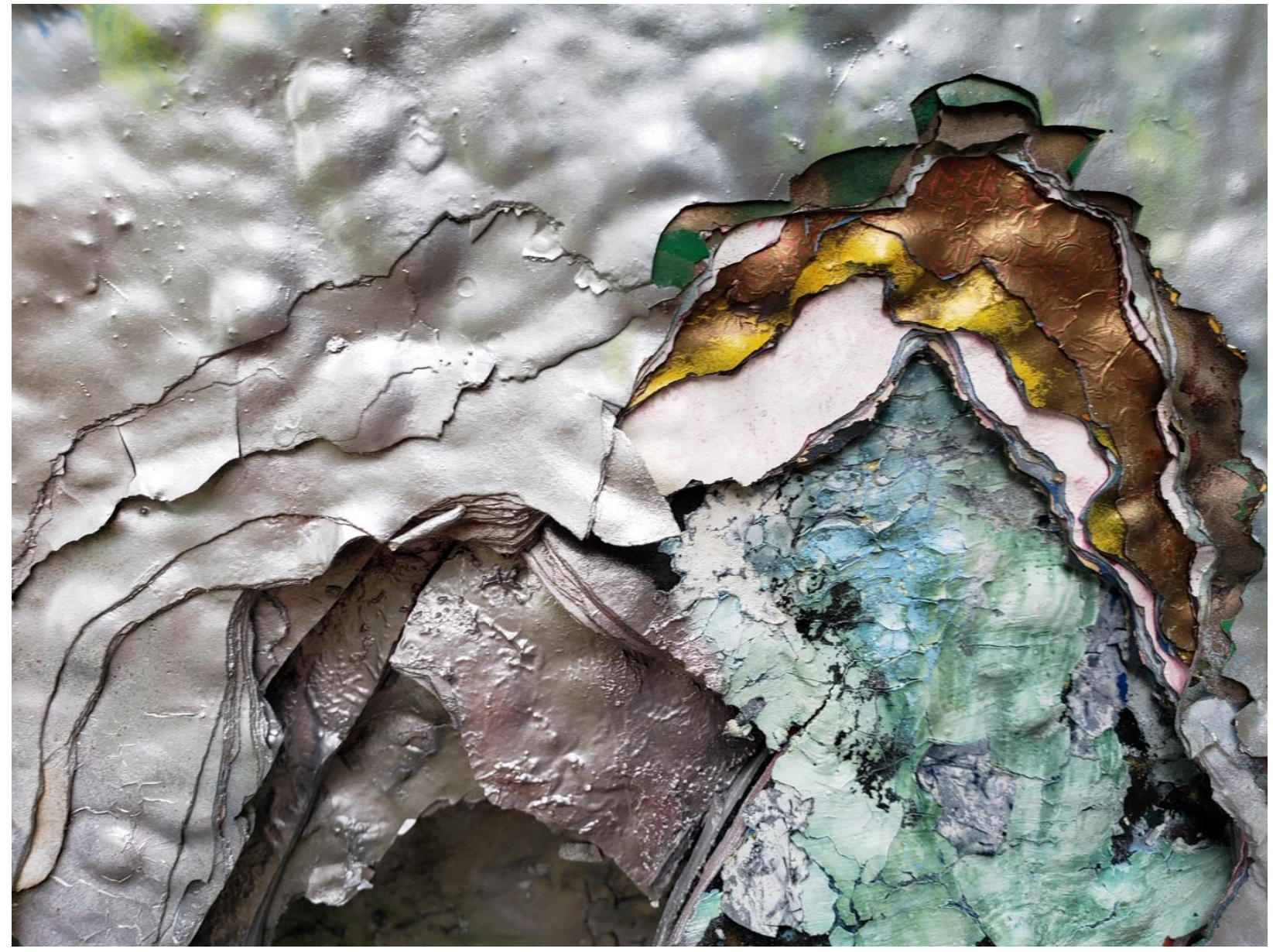

Figure 1. Peeling Layers of Paint (Campbell, Photograph, 2018)

Scraping away layers of spray-painted histories, empty cans and paint - stories, past and present begin to resurface. I have often passed the large graffitied rock that sits on campus grounds next to the highway, surrounded by age-old oaks and maples. An object of celebration symbolic of individual and community events and accomplishments. The in/animacy of rock. But there is something about this rock that troubles my thoughts - and each time I pass by, I begin to imagine the landscape from which it came - its removal and possession. The life beneath - and inability to breathe. I would expect nothing more than eye-rolls, if I were to express these sentiments to most. And not so long ago, I would have been right there with them thinking, "What is this woman talking about?" But as I continue unraveling histories seeped in colonial discourses, I begin to dig a little deeper - learning from different perspectives that continue to re/shape and/or dismantle my worldviews.

As a metaphor, this rock is symbolic of the many layers of stories that lay hidden beneath, narrative fragments and pieces that tell a greater story. The brightly painted surface 
often offering a celebration of accomplishments, community and events. But the rock has also been painted to commemorate the lives of loved ones, as well as to pronounce hate and again, painted or covered over (Soltis, 2009). The story of where it all began - the story of the rock, lost and/or forgotten. The many contributing artists working without pause to consider how their stories have been shaped by colonial histories and institutions. The same institutions and thinking that re/moved this rock, brought it here and named " $i t$ " a tradition.

Visiting the rock, I see the many layers of paint that form its surface are becoming heavy and in some areas beginning to lift or peel away, revealing the many under-layers - the rock surface beneath. As a settler to Canada and now resident in the United States, I continue to see reminders of such erasures, celebrations and cultural appropriation everywhere in Turtle Island/North America. It was never a land undiscovered or uninhabited (terra nullius), but alive in stories - and rocks, remember.

\section{The Storying of Places}

Places form the landscapes of our lives and memories - and are significant in shaping how we story our worlds. As Donald (2012) writes, "When researchers come to view themselves as storytellers, they become conscious of the ways in which their autobiography influences how they make sense of their lives and experiences" (p. 548). Donald highlights the use of Indigenous métissage as a research methodology that recognizes Indigenous values, ethics and ways of knowing. A way of resisting colonial frontier logics and an instrument through which Canadians might begin to confront their own understandings, memories, and learned histories of places, drawing on three metaphors: the fort, pentimento, and bricolage. The first metaphor, the fort, is often a prominent landmark in historic Canadian cities. Donald describes how most Canadians are protected by these fort walls, while Aboriginal people remain outside the safety and security of these reinforcements. The second metaphor, pentimento, is a borrowed art term which he uses to describe how colonial histories have 'painted over' Indigenous histories. Here Donald reminds us: "Pentimento implies a desire to peel back the layers that have obscured an artifact or a memory as a way to intimately examine those layers" (pp. 543-544). The third metaphor, bricolage, is a term used to describe the researcher as a weaver of a textual braid, drawing from diverse perspectives and ways of knowing. Donald further explains the importance of hermeneutics to Indigenous métissage, which does not seek to find solutions but engage in the ambiguity and difficulty of tension spaces, which he states also characterizes current Canadian/Indigenous relations. There is no prescribed methodology in hermeneutics, instead one must rely on one's own imagination and creativity to piece together one's story. And it is perhaps, through this process, that we might also begin to deconstruct colonial narratives and re/construct new ways of thinking.

Looking to the places where I (have) live/d and dwell/ed, I begin to unravel and re/story the meaning of these places. As Donald (2012) writes, "We must first reread and reframe colonial constructs in order to see more clearly the language and logics that have clouded our thinking" (p. 550). Peeling back the many layers to reveal rock beneath. Donald continues to explain how, "Such theorizing will help deconstruct the colonial frontier logics of inside/outside and facilitate meaningful reconstruction through sustained engagements that traverse perceived civilizational divides" (p. 550). As I begin to re/frame and re/consider the meaning of places within my own life, new/old stories begin to emerge. This métissage of stories illustrates how we might learn from different perspectives to perhaps better understand our responsibilities as newcomers and settlers to Indigenous peoples and places.

Cultural and Pedagogical Inquiry, Fall 2020, 12(2), pp. 95-105

ISSN 1916-3460 () 2020 University of Alberta

http://ejournals.library.ualberta.ca/index.php/cpi/index 


\section{The Living World}

Boulders have nothing to do with elephants, lichens are not horsetails, moss is not fur, spiders are not engineers, ravens do not haggle, and trees do not confer. Scientists are schooled to avoid such anthropomorphism... Yet if we entirely forgo such analogies, if we withhold our metaphors and stories, we estrange ourselves from the universe.

(Sanders, 2016, p. 218)

I begin the following discussion with a question: Do rocks talk? Pause a moment to consider the life and animacy of rock. What words would they whisper? What stories might they tell, if we could hear them speak? An anthropomorphism. An absurdity to most. Attributing qualities of life to the in/animate. But rocks tell the stories of the places from which they came, stories of the land, surrounding environments, bodies of water, dried riverbeds and the movement of continents. Crafted from a grain of sand, a meteor shower, a volcanic eruption - the earth and all her elements conspiring to give birth to their creation. Rocks are the oldest living beings (Donald, 2009; Tinker, 2004). Think for a moment of the lives they have witnessed, the changes they have seen, and the transformations they have experienced. Broken. Shattered. Dispersed. Elementary science teaches us how to identify different rock structures and how their compositions form their histories. As children, we are taught to objectify and categorize. A language of inanimacy that removes any notion of personhood and/or connection (Kimmerer, 2017). As Davis (2008) writes, “A Kwakwaka'wakw boy raised to revere the coastal forests as the realm of the divine will be a different person from a Canadian child taught to believe that such forests are destined to be logged" (p. 123). The ways in which we live in and understand our worlds are shaped by language and culture.

Kimmerer (2017) describes how the objectification of the living world is implicit within scientific language. "The practice of $i t$-ing everything in nature is not only prevalent, but is required in scientific writing" (para. 17). Science as a language values clarity and precision - an objective and/or neutral language, often considered to be "universal." However, this perception and understanding of science as universal is imbued with cultural meanings and value (Andreotti, Ahenakew, \& Garrick, 2011; Andreotti, 2016; Stein \& Andreotti, 2016; Stein, Hunt, Susa \& Andreotti, 2017). As Cajete (1994) states, "Science is a cultural system, and objectivity is really a subjective matter" (p. 197). Western science is one lens through which we might view and understand our worlds, but it is not the only one. Andreotti et al. (2011) describe how the production of truths in Western science is most often based on the exclusion of a diversity of knowledges. They argue that Indigenous knowledges are most often ignored within an academic context, thus removing all traces of culture, spirituality, and connection - the understanding of ourselves as part of nature, not above it. Cajete (1994) explains how Western education succeeded in removing stories from their context by presenting them as "data, description, theory, and formula" (p. 139), where students are left to reconnect the pieces, but are no longer able to do so, as "Their natural sense for story has been schooled out of them" (p. 140).

Kimmerer (2017) describes how children are naturally inclined to extend personhood to other living beings until corrected. Within the confines of Western science and English language, we are taught to objectify other living beings - and through this process internalize the belief that it is our right to own, possess - and even exploit the land for our own personal gain. "Western culture, through its unique play of history, disconnected itself from the natural world in order to conquer it" (Cajete, 1994, p. 82). This is not to dismiss or disregard the merit of Western science.

Cultural and Pedagogical Inquiry, Fall 2020, 12(2), pp. 95-105

ISSN 1916-3460 () 2020 University of Alberta

http://ejournals.library.ualberta.ca/index.php/cpi/index 
However, science as a privileged language and discipline, has also been used as a tool to suppress Indigenous knowledges. As a trained ecologist and Indigenous woman, Kimmerer (2013) believes that these two worldviews can coexist and offer us different ways of understanding the world: "Science polishes the gift of seeing indigenous traditions work with gifts of listening and language" (p. 48).

Language shapes the ways we think about the living world and/or objectify it. Kimmerer (2013) describes a language of animacy and how pronouns can change the way we think and act in relation to the living world. "Our words can be an antidote to human exceptionalism, to unthinking exploitation, an antidote to loneliness, an opening to kinship" (Kimmerer, 2017, para 21). In English, both the animate and inanimate are referred to as "it." There is no word to differentiate between object or subject, living beings other than human. She (2017) refers to the term, Aakibmaadiziiwin in Potawatomi, meaning "being of the earth," a pronoun used to refer to the many living beings, including rocks, extending personhood and respect, "to all who breathe and some who don't" (para. 6). She explains how the use and understanding of this pronoun, to refer to all living beings, challenges Western tenets of thinking:

The language we speak is an affront to the ears of the colonist in every way, because it is a language that challenges the fundamental tenets of Western thinking - that humans alone are possessed of rights and all the rest of the living world exists for human use. (para. 7)

Kimmerer offers an alternative to the English pronoun of "it." "With full recognition and celebration of its Potawatomi roots, might we hear a new pronoun at the beginning of the word, from the 'aaki' part that means land? $K i$ to signify a being of the living earth" (para. 20). She explains how we already have its plural form in English, kin. Many might argue that it would be impossible to change our use of pronouns, particularly considering the current political climate in the United States, where we refuse status to persons, let alone non-human living beings. However, Kimmerer, reminds us that throughout history, we have witnessed such changes:

Thankfully, human history is marked by an ever-expanding recognition of personhood, from the time when aboriginals were not seen as human, when slaves were counted as three-fifths of a person, and when a woman was worth less than a man. Language, personhood, and politics have always been linked to human rights... Naming is the beginning of justice. (para. 38)

Is it possible to change the ways we speak and think - to expand and offer respect to all living beings? I think of my daughter beginning to develop her language and voice - playing with sounds, words, gestures, and movements. She is finding new ways to express herself, observing and learning from the world around her. Speaking Farsi with her Dad, English as a family - and French, together. Instead of the single pronoun " $i t$," what if we were to offer them the pronoun of $k i$ or plural form kin? As Kimmerer writes: "The grammar of animacy is an antidote to arrogance; it reminds us that we are not alone." A language to express something, perhaps our children already know - the world is not for our taking, $k i$ is for our care. 


\section{$\operatorname{River} \operatorname{Rock}(k i / n)$}

This morning my daughter found a rock in the yard - and holding $k i$ in her hand, she beamed with pride, as she went to find her wagon to take her new friend for a ride. Stopping to show me her rock, I asked her if her new friend had a name, "Tika" (tickle tickle), she replied. Handing me the rock, I held $k i$ up to my ear as though $k i$ were talking to me. My daughter, delighted by this play, held $k i$ close to her lips as though whispering secrets to a friend - and in turn, holding $k i$ up to her ear, listening (ever so intently) to ki's reply. To the amusement of my husband, he laughed as he replied: "A child who talks to rocks and a wife who writes about them." Following a very intent conversation, she placed $k i$ back in her wagon - and began circling around the yard. Worried her new friend might be a potential choking hazard, I suggested that $k i$ was in fact a garden rock, whose home was in the garden, and offered her in exchange a larger (non-choking size) river rock. She happily accepted, and I suggested to my husband that perhaps they could take her new rock friend for a walk along the river to visit ki's kin (the other river rocks), so that I might return to my writing.

\section{Flying Rock (papamihaw asiniy)}

The stone was cold, so I picked it up and threw it in a pot of boiling water. Rocks don't bleed, they're nothing more than solid matter. But oh, the lives they've seen! Centuries passed. They stood watching as she fell from the sky and you to your knees (always a rock). And now you ask me to forget. Killing sentimentality, skipping stones. Centuries (past). Rocks have no feeling, no soul, no imagination - until they hit the ground. Flat prairie rock. "CRACK!” (Campbell, Journal, 2008)

We carry the memory of places with us - re/storying, re/imagining and re/living their significance and importance. Landmarks serve as reminders of places, evoking different meanings, memories and connections to places. Donald (2009) describes the significance of rocks to First Nations peoples of the Canadian Prairies, markers of the flat open land that can be seen from miles away. These rocks often served as a guide to travellers - and hold stories of the past. "Rocks are located at places that have a history—a story — and wisdom on how to live a good life that comes from looking closely at the place and listening carefully, over and over again, to the story" (p. 13). Donald explains that rocks are considered deeply spiritual, and as "...Animate entities, have an energy to them that is forever in flux - constantly changing, transforming, combining and recombining" (p. 13). He recounts the story of papamihaw asiniy or flying rock, the rock (or meteorite) that fell from the sky and landed in overlapping Cree and Blackfoot territory, in what today is known as Iron Creek in central Alberta, Canada. The event having been witnessed by both nations, named the rock: Papamihaw asiniy or "flying rock" by the Cree, and iihtsipáitapiiyo 'pa or "the Source of Life" by the Blackfoot (p. 14). The two nations believed the rock was sent by the Creator, as a reminder to the people, that no one might ever own the land or animals, but should be shared and cared for by all.

For many years, papamihaw asiniy remained in this place - and both nations visited the site to offer their thanks and prayers to the Creator (Donald, 2009). However, when Methodist missionary John McDougall arrived, he viewed: “... The spiritual reverence for papamihaw asiniy as a major obstacle to his Christianizing and civilizing efforts" (p. 15). And as the story goes, McDougall had the rock re/moved and placed in front of his Christian mission. The Elders prophesized that the rock's removal was a warning to the people - a sign of what was to come. A

Cultural and Pedagogical Inquiry, Fall 2020, 12(2), pp. 95-105

ISSN 1916-3460 () 2020 University of Alberta

http://ejournals.library.ualberta.ca/index.php/cpi/index 
time when the buffalo would become scarce and famine and disease would claim the lives of many, but the rock's journey continued:

Once McDougall realized that his possession of the flying rock did not bring him more converts to Christianity, he shipped papamihaw asiniy from his Victoria Mission to Ontario. It was placed on a pedestal between the two front doors of the chapel on the campus of Victoria College in Cobourg. ... Eventually, it was donated to the Royal Museum of Ontario, and the flying rock sat in that place for almost a century. (p. 16)

In the museum, papamihaw asiniy attracted the attention of many within the scientific community and became an object studied by scientists from around the world who took different samples and offerings. "Those offerings were sent away to strange places, further distanced from the Prairies where the flying rock had a place and a story that the people remembered" (Donald, 2009, p. 17). Over time and in a new place the story and memory of papamihaw asiniy or iihtsipáitapiiyo'pa was lost and/or forgotten. Scientific studies yielded data and information about the rock's structure and composition - and a new story was written.

Here Donald describes how the stories of artefacts housed in museums are often lost and/or forgotten:

The story of the artifact and the significance of the place that it comes from must be ignored. The artifact must be depersonalized and renamed, its original power and place must be removed and replaced so that it can be objectified, analyzed and shelved. (p. 17)

In 1973, papamihaw asiniy was returned to the Prairies, and flying rock has since been housed in the Royal Alberta Museum, Edmonton, Alberta - where the rock was renamed, Manitou Stone (Donald, 2009). "The removal of the rock allowed the place to be re-imagined and allowed the Prairies to be redefined in ways more conducive to Euro-Canadian notions of land use and ownership" (pp. 17-18). Donald describes how landscapes and cultural identities have been influenced and/or transformed by colonization and as a result, places hold different meanings to different people. Flying rock or papamihaw asiniy, is a symbol of landed immigration and how colonization changed the landscape - and through this process, places have become both Aboriginal and Canadian. Some believe papamihaw asiniy's rightful place is back on the land and that the rock's return would be a sign of healing for Aboriginal peoples.

\section{Listening To/Learning From - Doing the Work}

When we begin to re/envision ourselves in relation to places, the stories that reside in places - and how these places shape and in/form our identities, perhaps we might also begin to recognize our responsibilities to these places and peoples. As newcomers and settlers, how do we begin to re/build our relationships to the land and Indigenous peoples? There is only one land, and this place is home to both Indigenous and settler societies. As Fidyk (2013) describes, "It [home] symbolizes a life lived closely with 'Nature,' her rhythms, beauty, and cruelty. Life lived closely with seasons and the moon, letting one's pulse resonate with the waxing and waning of life light" (p. 314). The places we call home - and traces we leave behind. Kimmerer (2013) describes the consequences of such losses and dis/connection:

But I need to remember that the grief is the settlers' as well. They too will never walk in a tallgrass prairie where sunflowers dance with golden finches. Their children have also lost the chance to sing at the Maple dance. They can't drink the water either. (pp. 211-212)

Cultural and Pedagogical Inquiry, Fall 2020, 12(2), pp. 95-105

ISSN 1916-3460 @ 2020 University of Alberta

http://ejournals.library.ualberta.ca/index.php/cpi/index 
As newcomers and settlers, we have a great deal to learn from Indigenous peoples, cultures and political systems - if and when, we are ready to listen. As Basso (1996) writes, "When places are actively sensed, the physical landscape becomes wedded to the landscape of the mind, to the forming imagination, and where the mind may lead is anybody's guess" (p. 55). For those working in the field of curriculum studies, $\mathrm{Ng}$-A-Fook (2007) poses the question:

So then as "guest people," as curriculum theorists, as migrants, as academics with transnational citizenships, how can we make ourselves more readily available to listen and learn from the local Indigenous communities who traditionally inhabited and inhabit this land? (p. 21)

Learning from Indigenous peoples is not the same as learning about Indigenous peoples - and this requires that we put in the work. It is not the responsibility of Indigenous peoples to educate non-Indigenous peoples living on Turtle Island about our responsibilities as treaty members. We need to do our part and educate ourselves.

In an article by Deerchild (2018), Hayden King discusses territorial acknowledgments, stating he regrets helping Ryerson University write theirs, as it risks becoming "superficial" and does a "disservice to that treaty and those nations" (para. 11). King says he would prefer to see a framework through which people are required to write their own territorial acknowledgement to do the work. Territorial acknowledgements are mainly written for a non-Indigenous audience, and as King continues, "If we' re writing a script then providing a phonetic guide for how to recite the nation's names, then it doesn't really require much work on behalf of the people who are reciting that territorial acknowledgement" (para. 14). Such acknowledgements are often recited in spaces of privilege, including universities and conferences. Without having to do the "hard work," provides non-Indigenous peoples an alibi, instead of "...Learning about their neighbours and learning about the treaties of the territory and learning about those nations that should have jurisdiction" (para. 15). However, King also considers how in less privileged spaces, territorial acknowledgement might be used to start a conversation. In spaces of privilege, however, we need to be doing the work - and learning our responsibilities.

Here Ng-A-Fook (2007) poses the question: "Why doesn't the [Canadian] citizenship exam ask whose traditional land one lives on as one way to begin to redress the attempted erasure of Indigenous people from the land" (p. 15)? In September 2017, the federal government's Immigration, Refugees and Citizenship Canada announced the newly proposed citizenship oath would now include reference to Indigenous peoples and treaties based on the 2015 Recommendation of the Truth and Reconciliation Commission's (TRC) calls to action. Many argue that this change is long overdue, while others believe this is meaningless, if new citizens swearing the oath are not learning about Indigenous histories and treaties (Harris, 2017; Levitz, 2017). Up until these recently announced changes, all new citizens were required to take the citizenship oath, "swearing" or "affirming" their allegiance to the "Queen of Canada," which read as follows: "I swear (or affirm) / That I will be faithful / And bear true allegiance / To Her Majesty Queen Elizabeth the Second / Queen of Canada" (Immigration, Refugees and Citizenship Canada, 2015). McMahon (2017) argues that taking the oath creates a mockery of the Canadian Charter of Rights and Freedoms, upholds a doctrine of discovery, and further dismisses Indigenous peoples' histories and land rights. 
Swearing an oath and pledging allegiance, however, is not only limited to new citizens but also federal, provincial and territorial government employees and representatives. He argues that this is counter to the Truth and Reconciliation Commission of Canada's (TRC) call to action 45(i), which calls upon, "The Government of Canada, on behalf of all Canadians, to jointly develop with Aboriginal peoples a Royal Proclamation of Reconciliation to be issued by the Crown," which should include the commitment to: "Repudiate concepts used to justify European sovereignty over Indigenous lands and peoples such as the Doctrine of Discovery and terra nullius" (TRC, p. 5). Instead of showing its commitment to Indigenous peoples, the Canadian government and courts continue to uphold the existing oath and justify it because of symbolic relations to the monarch. "The courts are trying awfully hard to defend the discriminatory oath, pretending it is symbolic of some notion of equality values, while shielding it from any equality analysis at all" (p. 64). The recitation of an oath dismisses Indigenous peoples' histories and political systems - is this not a repetition, or continuation of an on-going colonial narrative?

\section{Ash and Rock}

Rocks circled the fire pit - covered in soot and ash. Years of build-up, blackened by flames. Where they came from, and how they got there, I'm not sure. They did not appear to belong to the landscape, perhaps they came from the shores of nearby Lake Erie. Shaped by the movement of water, rounded edges, and warmed by fires. Soft sandstone, no sharp or protruding edges. I imagine someone finding them and bringing them here. Stolen, given, taken. Mis/placed. Arranged in a circle, sinking deeper into the soil. As I began clearing the fire pit of waste and debris, metals and melted plastics - what I found was rock, beautiful old stones. Digging deeper, washing the rocks, one-by-one, removing the layers of build-up - to reveal the life and rock beneath. Sandstone, soft and red, as well as denser grey rocks. Different shapes, sizes and textures. Filling the wheelbarrow, I re/moved the rocks to the front flower bed - to create a garden border. They have been there for some time now, but each time I pass by - I think, this is not where they belong. They have more life and beauty than to sit and guard borders. Memories of places, warmed by the glow of fires and faces gathered round. Distant memories of the sea, swept or washed away.

To re/move, disperse, re/claim. Beneath the many layers of ash and debris, textures of life re/surface. Memories of the lives they have witnessed - and the stories they've been told. I begin to re/imagine a new place/space for them to dwell, surrounded by gardens to nourish and give them life. There is a stretch of green space in/between the neighbour's house and our own, where the daylight peeks through. This spring, I planted two young pawpaw saplings there. Trees that were given to community members, as part of an Earth Day initiative, to encourage people to re/introduce native species into their landscapes. This year, my daughter and I carried home two pawpaw saplings, two plum trees, a sumac bush and a bag of milkweed seeds - and this green space at the side of the house seemed the perfect place to plant these two young trees. It began with the two pawpaw saplings, and now, it is in the beginning stages of becoming a rock and native species garden. A space/place where pollinators, insect life and small animal species might live and dwell. As I begin to research and re/envision this space-moving, planting, and restoring habitats (and beauty in the process) - I continue to re/envision and witness its transformation. Pathways leading into the garden, barrels to divert and collect rainwater, and the rocks, still grounded. 
Washed by the wind and water, cracked, broken fragments of boulders, a grain of sand. I sometimes wonder what these old rocks think of this novice gardener, the patience they must have to watch and listen, as I stumble along my way. Thinking, re/imagining, not knowing where these pathways will lead. And while we often think of ourselves as masters of our own creations, working in the garden, digging our hands into the soil, fingernails full of dirt, planning, planting, and hoping seeds will grow. I know, they all have their own plans. Are they teaching me? And it is through this process, that I am learning that caring for the land is much more about listening (and hearing their response), knowing where to plant and what is needed, so that life can flourish - and rocks, might find rest.

\section{References}

Andreotti, V. (2016). The educational challenges of imagining the world differently. Canadian Journal of Development Studies, 37(1), 101-112.

Andreotti, V., Ahenakew, C., \& Garrick, C. (2011). Epistemological pluralism: Ethical and pedagogical challenges in higher education. AlterNative Journal: An International Journal of Indigenous Peoples, 7(1), 40-50.

Cajete, G. (1994). Look to the Mountain: An ecology of Indigenous education. Skyland, NC: Kivaki Press.

Davis, W. (2009). The Wayfinders: Why ancient wisdom matters in the modern world. Toronto, ON: Anansi Press.

Deerchild, R. (Host). (2019, January 18). 'I regret it': Hayden King on writing Ryerson University's territorial acknowledgement. CBC Radio: Unreserved. Retrieved from: https://www.cbc.ca/radio/unreserved/redrawing-the-lines-1.4973363/i-regret-it-haydenking-on-writing-ryerson-university-s-territorial-acknowledgement-1.4973371?fbclid =IwAR2wQkyA_uOTo9JtVlmKlbwo_nRdWoOZZ6rE77JA-LUj4-8Dufkj7Ob2V2o

Donald, D. (2012). Indigenous métissage: A decolonizing research sensibility. International Journal of Qualitative Studies in Education, 25(5), 533-555.

Donald, D. T. (2009). Forts, curriculum, and Indigenous métissage: Imagining decolonization of Aboriginal-Canadian relations in educational contexts. First Nations Perspectives, 2(1), $1-24$.

Fidyk, A. (2013). An ethic of humility. In C. Chambers, E. Hasebe-Ludt, C. Leggo \& A. Sinner (Eds.), A Heart of Wisdom: Life Writing as Empathetic Inquiry (pp. 306-315). New York, NY: Peter Lang.

Harris, K. (2017, February 2). New Canadians to pledge honour for Indigenous treaties in revised citizenship oath. $C B C$ News. Retrieved from: https://www.cbc.ca/news/politics/citizenship-oath-indigenous-treaties-1.3963508 
Immigration, Refugees and Citizenship Canada. (2015, December 22). Oath of Citizenship. Retrieved from: https://www.canada.ca/en/immigration-refugeescitizenship/corporate/publications-manuals/operational-bulletins-manuals/canadiancitizenship/ceremony/oath.html

Kimmerer, R. (2017, March/April). Speaking of nature. Orion Magazine. Retrieved from: https://orionmagazine.org/article/speaking-of-nature/

Kimmerer, R. W. (2013). Braiding sweetgrass: Indigenous wisdom, scientific knowledge, and the teaching of plants. Minneapolis, MN: Milkweed Editions.

Levitz, S. (2017, September 25). New citizenship oath to reference treaties with Indigenous Peoples. The Globe and Mail. Retrieved from: https://www.theglobeandmail.com/news/national/new-citizenship-oath-to-referencetreaties-with-indigenous-peoples/article36419046/

Ng-A-Fook, N. (2007). An Indigenous curriculum of place: The United Houma Nations contentious relationship with Louisiana's educational institutions. New York, NY: Peter Lang.

Sanders, S. R. (2016). Mind in the forest. In N. Brodie, C. Goodrich \& F. J. Swanson (Eds.), Forest under story: Creative inquiry in an old-growth forest (pp. 214-225). Seattle, WA: University of Washington Press.

Soltis, K. (2009, Dec. 8). A rock, and a tradition. Daily Kent Stater. Retrieved from: https://dks.library.kent.edu/?a=d\&d=dks20091208-01.2.32\&e=-------en-20--1--txt-txIN-------

Stein, S., Hunt, D., Susa, R., \& Andreotti, V. (2017). The educational challenge of unraveling the fantasies of ontological security. Diaspora, Indigenous, and Minority Education, 11(2), 69-79.

Stein, S., \& Andreotti, V. (2016). Cash, competition, or charity: International students and the global imaginary. Higher Education, 72, 225-239.

Tinker, G. (2004). The stones shall cry out: Consciousness, rocks, and Indians. Wicazo Sa, 19(2), 105-125.

Truth and Reconciliation Commission of Canada (TRC). (2015). Truth and Reconciliation Commission of Canada: Calls to action. Retrieved from: http://nctr.ca/assets/reports/Calls_to_Action_English2.pdf 